\title{
Consideraciones sobre la Virgen de la Capilla
}

Durante la pasada anualidad (2009-2010) y por encargo de la Consejería de Cultura de la Junta de Andalucía, se realizó en los talleres del Instituto Andaluz del Patrimonio Histórico (IAPH) el proyecto de conservación e intervención de la Virgen de la CapiIla, procedente de la iglesia de San Ildefonso de Jaén, imagen que ostenta entre otros los títulos de patrona de la ciudad (1950), Alcaldesa Mayor (1967) y es Bien de Interés Cultural desde 1988.

La historia material de la imagen de la Virgen de la Capilla (escultura en madera tallada y policromada $77 \times 27 \times 21 \mathrm{~cm}$ ) ha supuesto un ejercicio no exento de riesgo, sin evitar caer en la reducción o la mera enumeración de opiniones. El interés desde un punto de vista histórico ha sido definir los límites de la intervención, marcado por cuatro interrogantes sobre la imagen: autoria, si formó parte de un retablo, fecha de ejecución y por último lo relativo a la materialidad de la obra, es decir, si era una única pieza.

En principio estaba la lógica e inevitable labor de recopilar todas las fuentes documentales y bibliográficas, esta información venia determinada por una constante dualidad. La relacionada con el origen milagroso de la imagen (el episodio del "descendimiento") y la perspectiva histórico-artística de la escultura.

La particularidad del supuesto origen ha provocado que los estudios sobre la misma siguieran dos líneas de investigación muy claras: en primer lugar todo lo referente a la veracidad de la naturaleza histórica del descendimiento, y en segundo lugar la consecuente justificación religiosa o teológica del hecho milagroso. Esta circunstancia provocó un vacío bibliográfico en aspectos artísticos suplidos parcialmente a partir de la segunda mitad del siglo XX.

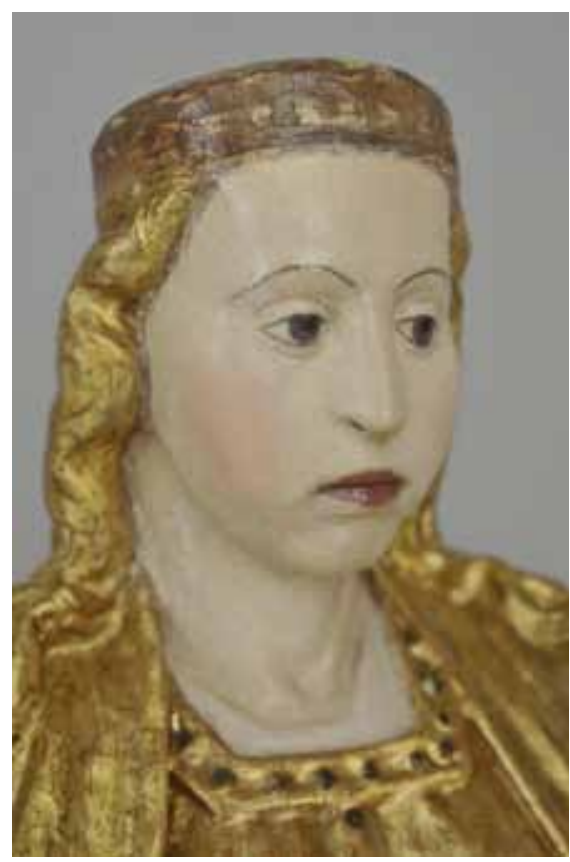

Detalle de la cabeza de la Virgen una vez restaurada. Fuente: Fondo Gráfico IAPH

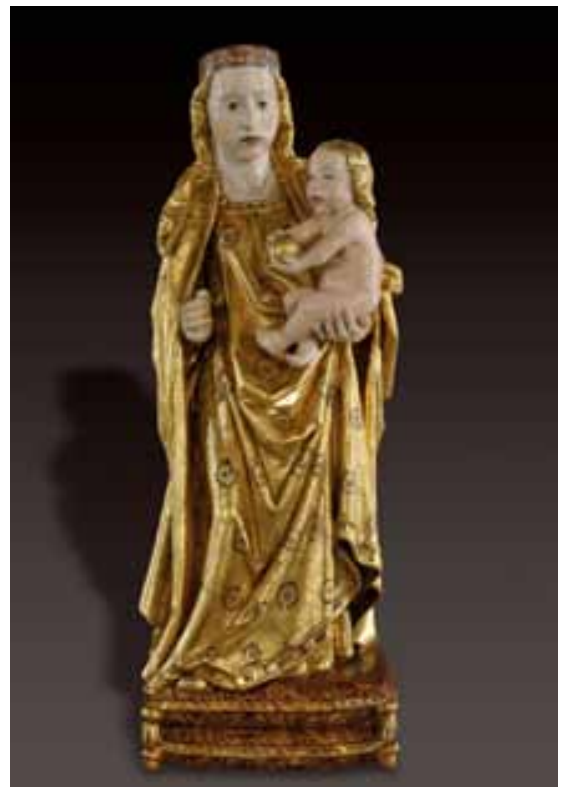

Imagen restaurada de la Virgen de la Capilla

Desde un punto de vista historiográfico los intereses a lo largo de la historia han ido evolucionando: por un lado, la preocupación de los estudiosos estaba en atestiguar y autentificar el citado episodio con rigor histórico, y por otro, justificarlo desde un punto de vista religioso para constatar el milagro. En torno a ello se ha ido construyendo una amplia geografía de escritos y publicaciones desde diferentes prismas: el marco temporal y físico del descendimiento, los personajes o las circunstancias han Ilenado numerosas páginas orientadas a certificar el hecho milagroso.

A través de los textos de la época y hasta bien entrado el siglo XX, se puede constatar cómo este interés ha sido ampliamente versionado y aumentado desde todos los aspectos: teológico, paleográfico, etc.

La imagen de la Virgen de la Capilla ha suscitado la atención de diferentes personajes históricos pretendiendo cada uno dar respuestas a intereses diversos influenciados por las circunstancias de su tiempo. Podemos encontrar cómo el episodio del descendimiento es utilizado como instrumento de búsqueda de identidad o construcción de un pasado glorioso de la ciudad de Jaén. Como ejemplo, el humanista Gaspar Salcedo Aguirre (1545-1632) fija en ella su atención dedicando en su obra Relación de algunas cosas insignes que tiene este Reyno y Obispado de Jaén (1614) un capítulo al santuario de la Virgen de la Capilla, como uno de los centros religiosos importantes de la ciudad. Ya recogido anteriormente también por Argote de Molina.

Este citado interés ha variado según las épocas y las demandas sociales. Dentro de la amplia producción bibliográfica podemos distinguir una vertiente con más carga devocional y otra dedicada a aspectos históricos.

Con respecto a los primeros, aún no siendo éste el objetivo de estas líneas, se debe mencionar la riqueza abrumadora de escritos de carácter devocional que ha suscitado la Virgen. Desde el siglo XVII la imagen ha sido un centro importante de la espiritualidad del pueblo jiennense.

Sin embargo desde el punto de vista del historiador del arte empiezan a surgir diferentes preguntas acerca del origen (no ya de la devoción en sí), que lógicamente ha sido constatado, sino el origen de la escultura basándose en elementos meramente estilísticos ya que no existe documentación concreta.

El siglo XX iniciará una nueva andadura hacia el conocimiento de la imagen siendo la primera vez que se conozca o reconozca la imagen sin vestir, con autores como Alfredo Cazabán Laguna que publicará en su famosa revista Don Lope de Sosa fotografias de la misma y sobre todo el estudio de Vicente Montuno Morente de 1950, que serán clave para un conocimiento más riguroso.

Los esfuerzos han continuado y se han sumado nuevos estudiosos, publicaciones específicas cuyo fin es la difusión y la investigación de la imagen y su entorno. Es en esa etapa de revaloración cuando surge por primera vez la necesidad de restaurar la imagen (1983).

Hemos pretendido hacer una reconstrucción historiográfica como una forma de reconocer algunos de los valores y conceptos ligados a la obra.

Al comienzo del texto establecimos cuáles eran los puntos cardinales fundamentales para el conocimiento de la imagen. Respecto a su origen la obra es fruto de su contexto histórico surgiendo en un sector de la ciudad -arrabal de San Ildefonso- marcado por la inestabilidad, y produciendo un hecho que servirá como aglutinante o nexo de unión. Desde un punto de vista devocional es similar a otras imágenes ligadas a episodios bélicos en época de reconquista.

Sobre su autoría, por los rasgos estilisticos que presenta, todavía arcaicos, podemos enmarcarla dentro de la producción de un artista andaluz cuya formación fuese flamenca; respecto a otros elementos de comparación -la policromia-, las diferentes intervenciones han supuesto una merma en el aporte de información y sobre todo porque los cambios de criterios y necesidades según la época han dado una visión menos ajustada de la realidad. Por su disposición, su único punto de vista frontal y la simplificación de su espalda inducen a pensar que con toda probabilidad fue realizada para situarse en un retablo. Por último tras la intervención se han ampliado los conocimientos a nivel interno de la obra, realizada de una sola pieza en madera de nogal.

Éstas son sólo algunas notas en torno a la imagen. La obra reúne por sí sola no sólo valores estéticos o culturales sino que además, desde su origen, es testigo del devenir colectivo de la ciudad de Jaén.

\section{Valle Pérez Cano}

Centro de Intervención en el Patrimonio Histórico del IAPH 